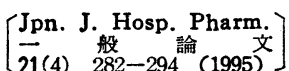

\title{
高齢者の服薬介助における負担度の定量解析の試み
}

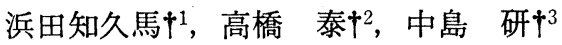 \\ 東京大学医学部薬剤度学教室 ${ }^{1}$ \\ 東京大学病院中央医療情報部 $\dagger^{2}$ \\ 東京理科大学薬学部 ${ }^{3}$
}

\section{Quantitative Analysis of the Factors Affecting the Burden on Administering Medicine to the Elderly}

\author{
Chikuma Hamada $\dagger^{1}$, TaI Takahashi $\dagger^{2}$ and Ken NaKajima $\dagger^{3}$ \\ Pharmacoepidemiology, Faculty of Medicine, University of Tokyo ${ }^{1}$ \\ Hospital Computer Center, University of Tokyo Hospital† ${ }^{2}$ \\ Faculty of Pharmaceutical Sciences, Science University of Tokyo ${ }^{3}$
}

( Received February 21, 1995)

\begin{abstract}
Quantitative analysis of the relationship between the burden on care-givers while administering medicine to the elderly and the factors which affect this burden were carried out at six longterm facilities in Japan. For grading the burden of administering drugs, we used the method developed by Tsutsui, in which the burden of 128 kinds of care services are quantitatively standardized from 1 point (turning on the TV) to 100 points (contending with violence by confused elderly). According to the method, caregivers graded the burden of every resident when administering the drugs. At the same time, various factors of every resident which influenced to some extent the burden of administering the drugs, were investigated.
\end{abstract}

The results of this study led us to two important conclusions.

1) As for the distribution of the burden score, most cases received around 20 points (equivalent to the preparation of a meal). The pattern of the score distribution differed widely among institutions.

2) To analyze the relationship between the burden score and some other factors, a multiple regression model was constructed. The dependent variable of the model was the burden score and the explanatory variables comprised several kinds of functional levels of aged people, the disparities among institutes. The model indicated that the factors which strongly affect the burden score are difficulty in swallowing, mental function level, physical activity level, the number of medicines prescribed, and malfunctioning of the hands. The R-square of this model was 0.60 .

Keywords_-burden score, multiple regression, elderly, administering medicine care

$\dagger^{1,2}$ 東京都文京区本郷 7 丁目 3-1；3-1, Hongo 7chome, Bunkyo-ku, Tokyo, 113 Japan

$\dagger^{3}$ 東京都新宿区市ヶ谷船河原町 $12 ； 12$, Funagawara-cho, Ichigaya, Shinjuku-ku, Tokyo, 162 Japan
はじめに

わが国の人口の高齢化は 1955 年頃に 65 歳以上の 人の割合が $5 \%$ であったときから始まる、総務庁 統計局の人口推計によると, 1994 年 8 月 1 日現在, 
日本の人口 1 億 2485 万人中, 65 歳以上の高齡者人 口は 1749 万人で $14 \%$ を占めている. 高龄者の割合 は約 40 年間で $10 \%$ 近く増加し, 社会の高龄化が急 速に進んでいる，厚生省の将来推計人口による と, 高齢者人口の割合は 2000 年には $17 \%, 2015$ 年 以降は $23 \%$ に達するとみられている. 人口高齢化 は, 経済や社会の多くの側面に影響を与え, 医療 や社会福祉の体制の変化が必要になる. 痴呆や寝 たきり老人などの要介護老人のケアが社会的な問 題になりつつある. 現在わが国では, 高龄者の主 な療養施設として, 医療施設である一般病院, 老 人病院, 中間施設と位置づけられる老人保健施 設, さらには福祉施設として特別養護老人ホーム がある。

高㱓者では慢性疾患を罹患しやすく，また多蔵 器疾患を伴う場合が多いという特徴があるため, 複数の薬剤が併用されることが多くなる．このた め通常の人に比べ服薬に関連して様々な問題が生 じやすい. 高齢者の服薬回数, 服薬困難なケース, 與下障害等がある高路者に服薬させるための工夫 について，研究報告が多数なされている1-3).また 痴呆による拒薬や㯖下障害を抱えた高齢者が増え てきたことにより，服薬の介助が重要な課題にな りつつある4).

本報では, 高齢者の服薬介助を行うときの介護 者の負担度を 0 100 点で定量的に評価し, 「服薬 介助の負担」と高齢者の機能レベルとの関連や施 設間差について調べた。

\section{方法}

\section{1. 服薬介助の負担度スコアと対象データ}

[介護負担度スコア】

介護業務には負担の軽い業務から非常に重いも のまである．負担感を標準化して定量的に評価す ることは，ケアのあり方を考える上で有用である. 筒井 ${ }^{5)}$ は介護職員の主要な業務とされる「身の回 りの世話」 128 項目の総合的な負担感を点数化し た. 点数が大きくなる汇ど業務の負担は重くな る. 10点刻みに基準化されたスコアに対応する作 業は,
1点: テレビのオンオフ
10 点: 护やつの後始末
20 点：食事準備
30 点: ポータブルの後始末
40 点 : 洗髮の介助
50点: オムツ交換時陰部洗浄
60 点：食事介助全面
70点：リネン交換
80 点：入浴時の着替え
90 点: 移乗
100 点: 痴呆性老人の暴力対応

となる. そこで高齢者の服薬介助に伴う負担が， 他の介護作業と比べてどの程度であるかを, 介護 負担度スコアに基づいて定量的に評価した。本調 查では，薬剤を渡すだけで高㱓者が自分で服薬を 行うようなケースは 0 10 点, 袋・ヒートシール から薬を取り出し，薬を领み込むまでそばにつき そう場合は20〜 50点，拒薬や黇下障害があり服薬 介助が困難なケースは70点以上の高い点数が付け られた。

\section{[調查対象者】}

老人病院, 老人保健施設, 特別養護老人ホーム から各 2 施設を対象施設として選んだ4).「老病」 とは介護力強化病院の指定を受けた特例許可病院 (いわゆる老人病院), 「老健」は老人保健施設, 「特養」は特別養護老人ホームを意味する，各施 設で介護を行っている職員 (看護婦, 薬剤師等) に対して, 高路者の基本運動機能(聴覚, 視覚等), 活動機能レベル (食事, 排泄等の機能), 問題行 動, 疾患の有無, 服薬介助の内容・負担感につい てアンケート調査を行った。

\section{2. 解析方法}

1）服薬介助負担度スコアの分布型を, ヒスト グラムと要約統計量によって記述し，施設間差に ついて分散分析によって検討した。

2）服薬介助負担度スコアと, 疾患の有無, 問 題行動の有無, 基本運動機能, 活動機能レベル, あるいは服薬介助の方法等の因子との関連につい て相関分析を行った．それらの変数の多くは 2 值 データないし順序のあるカテゴリカルデータであ るため, 関連を要約する指標として, 2 次元正規分 布を前提としたPearsonの相関係数ではなく, 
分布型を特定しないSpearman の相関係数を用 いた．関連の有意性については，2 值データはウ イルコクソン検定, 順序カテゴリカルデータは, Spearman の相関係数に基づいて検定を行っ $た^{6)}$.

3）各患者・入居者ごとの服薬介助負担度スコ ア（0１00点）を目的変数Yとし，高㱓者の機能 レベルや施設間差などを説明変数 Xとした重回帰 分析 ${ }^{7)}$ を行った．解析においては以下のモデルを 仮定した。

$$
\mathrm{Y}=\alpha+\beta_{1} \mathrm{X}_{1}+\beta_{2} \mathrm{X}_{2}+\beta_{3} \mathrm{X}_{3}+\cdots \cdots+\varepsilon
$$

ただしには対象者ごとに独立に同一の正規分 布にしたがう確率変量とする，計算にはSAS (Statistical Analysis System) の REG プロ シジャ6)を用いた.

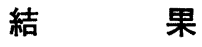

Table 1 亿各施設に括ける調査者数, 服薬必要 者数を示す。ここでいう服薬は経口薬を対象とす るもので注射，点滴，外用薬のみを服薬している 患者は除いている.

解析では, 全調査者 536 名のうち経口薬が常用

Table 1. 各施設の服薬必要者数

\begin{tabular}{|c|c|c|c|c|}
\hline 分類 & 略名 & 調查者数 & 服薬数 & 割合 $(\%)$ \\
\hline 老人病院 1 & 老病 1 & 84 & 79 & 94.1 \\
\hline 老人病院 2 & 老病 2 & 75 & 66 & 88. 0 \\
\hline 老人保健施設 1 & 老健 1 & 142 & 61 & 43.0 \\
\hline 老人保健施設 2 & 老健 2 & 80 & 78 & 97.5 \\
\hline 特別盖護老人ホーム 1 & 特釱 1 & 55 & 49 & 98.0 \\
\hline 特別養護老人ホーム 2 & 特養 2 & 100 & 76 & 76.0 \\
\hline 部 & & 536 & 409 & 76.3 \\
\hline
\end{tabular}

Table 2. 各施設の性別と年齢の構成

\begin{tabular}{|c|c|c|c|c|c|c|}
\hline 施設 & 性別 & $N$ & 最小 & 最大 & 平均 & 標潐偏差 \\
\hline 老病 1 & $\begin{array}{l}\text { 男 } \\
\text { 女 } \\
\text { 計 }\end{array}$ & $\begin{array}{l}27 \\
52 \\
79\end{array}$ & $\begin{array}{l}60 \\
63 \\
60\end{array}$ & $\begin{array}{l}92 \\
96 \\
96\end{array}$ & $\begin{array}{l}78.1 \\
82.1 \\
80.7\end{array}$ & $\begin{array}{l}9.4 \\
7.7 \\
8.5\end{array}$ \\
\hline 老病 2 & $\begin{array}{l}\text { 男 } \\
\text { 女 } \\
\text { 計 }\end{array}$ & $\begin{array}{l}19 \\
47 \\
66\end{array}$ & $\begin{array}{l}53 \\
60 \\
53\end{array}$ & $\begin{array}{l}92 \\
95 \\
95\end{array}$ & $\begin{array}{l}75.0 \\
82.0 \\
80.0\end{array}$ & $\begin{array}{r}10.5 \\
7.3 \\
8.9\end{array}$ \\
\hline 老健 1 & $\begin{array}{l}\text { 男 } \\
\text { 女 } \\
\text { 計 }\end{array}$ & $\begin{array}{l}14 \\
47 \\
61\end{array}$ & $\begin{array}{l}73 \\
65 \\
65\end{array}$ & $\begin{array}{l}90 \\
96 \\
96\end{array}$ & $\begin{array}{l}80.9 \\
82.7 \\
82.3\end{array}$ & $\begin{array}{l}6.1 \\
6.6 \\
6.5\end{array}$ \\
\hline 老健 2 & $\begin{array}{l}\text { 男 } \\
\text { 女 } \\
\text { 計 }\end{array}$ & $\begin{array}{l}19 \\
59 \\
78\end{array}$ & $\begin{array}{l}68 \\
65 \\
65\end{array}$ & $\begin{array}{l}97 \\
93 \\
97\end{array}$ & $\begin{array}{l}83.3 \\
82.0 \\
82.3\end{array}$ & $\begin{array}{l}6.1 \\
6.5 \\
6.4\end{array}$ \\
\hline 特羪 1 & $\begin{array}{l}\text { 男 } \\
\text { 女 } \\
\text { 計 }\end{array}$ & $\begin{array}{l}12 \\
37 \\
49\end{array}$ & $\begin{array}{l}60 \\
66 \\
60\end{array}$ & $\begin{array}{l}81 \\
95 \\
95\end{array}$ & $\begin{array}{l}71.3 \\
80.0 \\
77.8\end{array}$ & $\begin{array}{l}6.7 \\
7.3 \\
8.0\end{array}$ \\
\hline 特善 2 & $\begin{array}{l}\text { 男 } \\
\text { 女 } \\
\text { 計 }\end{array}$ & $\begin{array}{l}12 \\
64 \\
76\end{array}$ & $\begin{array}{l}61 \\
60 \\
60\end{array}$ & $\begin{array}{l}91 \\
99 \\
99\end{array}$ & $\begin{array}{l}76.9 \\
83.8 \\
82.7\end{array}$ & $\begin{array}{l}7.8 \\
7.0 \\
7.5\end{array}$ \\
\hline & 合計 & 409 & 53 & 99 & 81.2 & 7.8 \\
\hline
\end{tabular}


されかつ服薬介助負担度スコアが評価された, 409 名を対象とした。経口薬を常用する高齢者の割合 は老健 1 を除いては，75\%を越えていた。老人病 院では経口薬を常用する患者の割合が $94 \%$ と $88 \%$ となった，また特別養護老人ホームでも，経口薬 を必要とされる高齢者の割合がかなり高かった (98\%と76\%). Table 2 に各施設ごとの性別と 年齢の構成を示した．各施設の高齢者の平均年齢 はいずれも75歳以上であり，施設間で大きな違い は認められなかった。 また男女比については，最 も女性が少ない老病 1 の $1: 1.9$ から最高の特養 2 の $1: 5.3$ まで，施設によって比較的大きくば らついた.

\section{1. 服薬介助負担度スコアの施設間の比較}

施設ごとの服薬介助負担度スコアと全体の要約 統計量を Table 3, ヒストグラムを Fig. 1 に示 した。

服薬介助の負担度として 20 点前後と答えた人が 多かった．自ら服薬することができない高齢者に 対しては, 介護者が必要な薬剤を複数選択し，

PTP，ヒートシール包装から錠剤，カプセル剂を 取り出す必要が生じ，この負担が筒井の介助負担 度スコアの “食事準備”程度に相当すると考兄ら れた。 また負担度に大きな施設間差が見られ，服 薬介助が非常に大変な施設とそれほどではない施 設が存在した。負担度スコアの施設間差について

Table 3. 施設ごとの服薬介助負担度アコアと全体の要約統計量

\begin{tabular}{|c|c|c|c|c|c|c|c|}
\hline 施陪 & $\mathrm{N}$ & 平均 & 標淮偏差 & メディアン & モード & 最小 & 最大 \\
\hline 老㾈 1 & 79 & 47.9 & 25.1 & 50 & 50 & 0 & 100 \\
\hline 老瘁 2 & 66 & 28.0 & 30.1 & 20 & 0 & 0 & 100 \\
\hline 老梴 1 & 61 & 7. 1 & 13.1 & 0 & 0 & 0 & 60 \\
\hline 芦健 2 & 78 & 22.6 & 16.2 & 20 & 10 & 5 & 70 \\
\hline 特養 1 & 49 & 23.6 & 16.4 & 20 & 30 & 0 & 70 \\
\hline 特禖 2 & 76 & 12.8 & 16.8 & 10 & 0 & 0 & 80 \\
\hline 部 & 409 & 24.3 & 24.5 & 20 & 0 & 0 & 100 \\
\hline
\end{tabular}

(a)

级慗介别の負担度

FREQ.

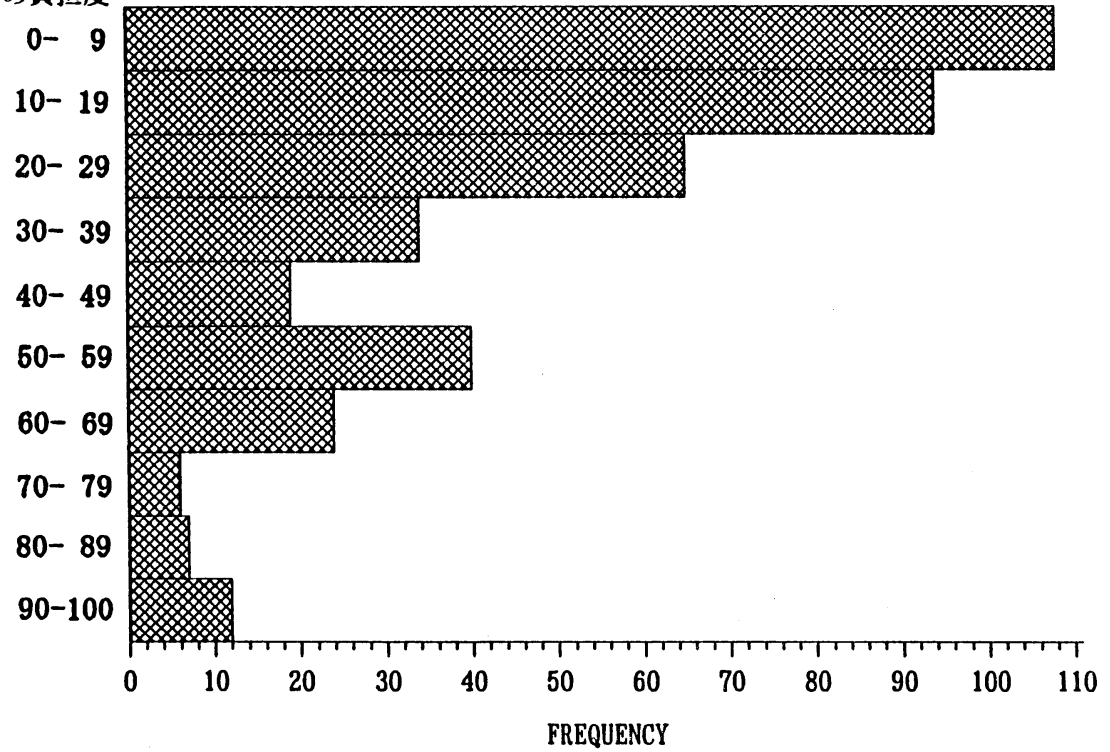

108

94

65

34

19

40

24

6

7

12

Fig. 1. 服薬介助の負担度のヒストグラム 
(b)

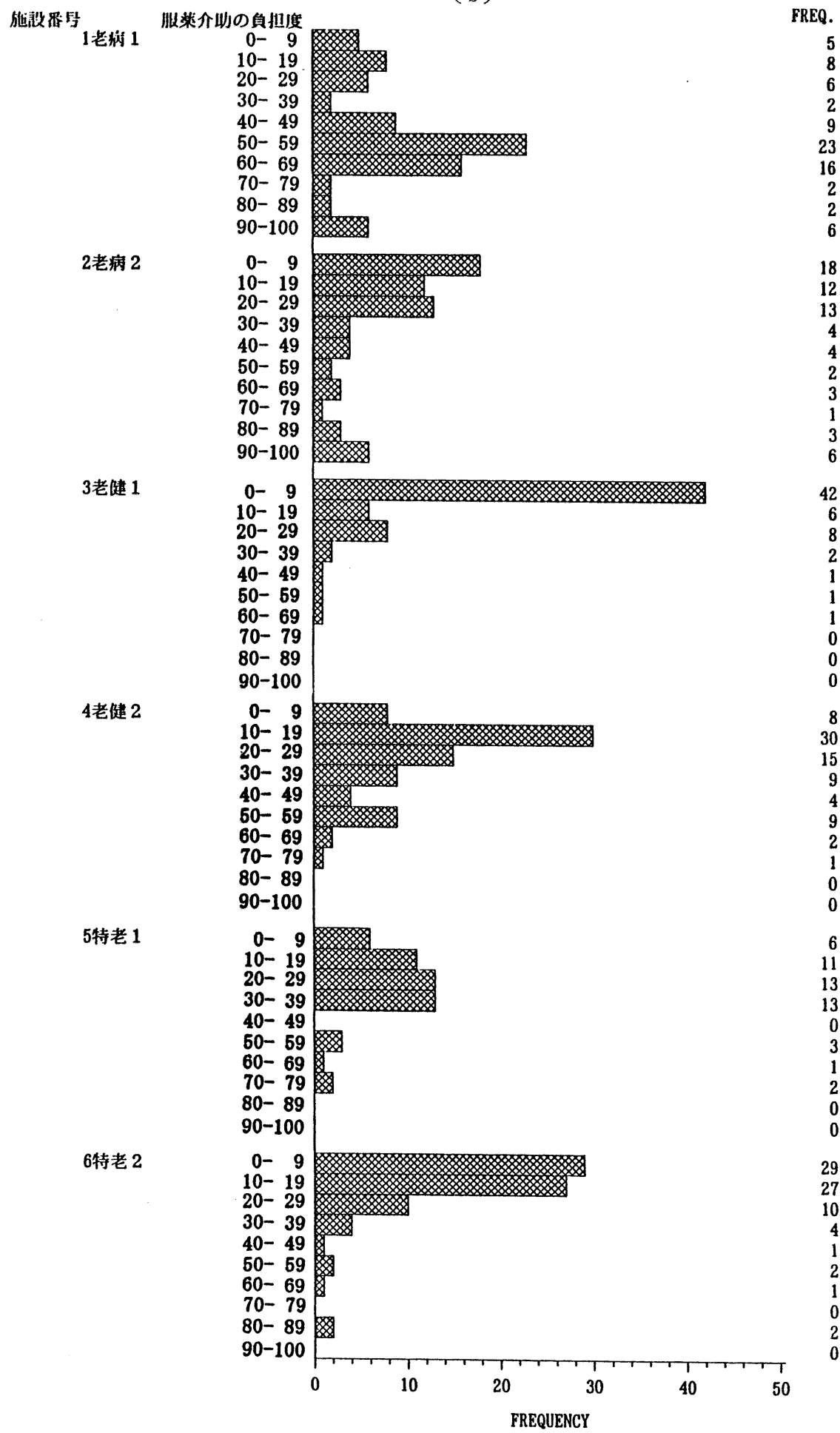

Fig. 1-2. 服薬介助の負担度のヒストグラム（つづき） 
一元配置分散分析を適用した結果， $\mathrm{F}$ 値は 34.2 と なり，施設内の分散に比べ施設間の分散が 30 倍以 上あった．施設間変動の寄与率は 0.298 であり, 全体の変動のうちの約 $30 \%$ 施設間差が占めてい

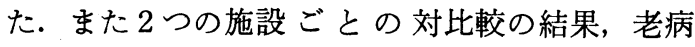
2 , 老健 2 , 特養 1 の 3 施設の間では負担度スコ アに有意な差はなく, この 3 施設に比べて, 老病 1 では負担度スコアの平均值が有意に高く, 老健 1 と特養 2 では有意に低かった。今回対象とした 施設では服薬介助負担度スコアは老健, 特養に比 較して老病で高い傾向があったが，同じ老人病院 でも老病 1 は老病 2 に比べて 20 点程度, 平均值が 高く, 同一の施設区分の中でも大きな差が存在し た. 老龄 1 では $2 / 3$ の高龄者について服薬介助負 担度は 0 であり (Table 4), この施設を含めた老 健，特養の 4 施設では，スコアが50（オムッ交換 時陰部洗浄に相当）以上の高龄者の割合は $10 \%$ 前 後 $(3,15,12,7 \%)$ である. 一方老病 1 では62 $\%$ ，老病 2 では $23 \%$ が存在し，またスコアが 80 （入浴時の着替えに相当）以上の患者も，それぞ
れ 1 割程度 $(10,14 \%)$ 存在した。 さらにスコア が 100 （痴呆性老人の暴力対応に相当）の患者は それぞれ 5 人， 2 人であった。スコアが 100 の高 齢者はいずれも曣下障害があり (Table 5), やむ をえない事情によって粉状に加工してから服薬す る場合もあるとのことであった，薬が喉につまっ たりすることがあり，介護者は高龄者が薬を飲み 込むのを確認するため，服薬が終了するまでそば につく必要があった， 1 回当たりの服薬介助に必 要な時間は 30 分〜 1 時間程度であり, 正常人では ほとんど負担にならない服薬行動が，鱟下能力が 著しく低下している高龄者ではかなりの負荷のか かる作業であり，それに伴い介助者にも大きな負 担が生じる.

\section{2. 服薬介助負担度スコアの他の因子の関連の}

\section{解析}

負担度スコアと他の因子との関連について相関 分析を行った（Table 6〜9). 年齢, 性別, 問題 行動の有無等は負担度スコアとの関連はみられな かったので，記載してない. Table 6〜9 におけ

Table 4. 服薬介助負担スコアの施設間の比較

\begin{tabular}{|c|c|c|c|c|c|}
\hline 施 設 & $N$ & 0の度数 & 50 以上 & 80 以上 & 100 \\
\hline $\begin{array}{l}\text { 老病 } 1 \\
\text { 老病 } 2 \\
\text { 老健 } 1 \\
\text { 老健 } 2 \\
\text { 特食 } 1 \\
\text { 特善 } 2\end{array}$ & $\begin{array}{l}79 \\
66 \\
61 \\
78 \\
49 \\
76\end{array}$ & $\begin{array}{r}4(5.1 \%) \\
18(27.3 \%) \\
41(67.2 \%) \\
0(0.0 \%) \\
1(2.0 \%) \\
26(34.2 \%)\end{array}$ & $\begin{array}{r}49(62.0) \\
15(22.7) \\
2(3.3) \\
12(15.4) \\
6(12.2) \\
5(6.6)\end{array}$ & $\begin{array}{l}8(10.1) \\
9(13.6) \\
0 \\
0 \\
0 \\
2(2.6)\end{array}$ & $\begin{array}{l}5(6.3) \\
2(3.0) \\
0 \\
0 \\
0 \\
0\end{array}$ \\
\hline & 409 & $90(22.0 \%)$ & $89(21.8)$ & $19(4.7)$ & $7(1.7)$ \\
\hline
\end{tabular}

Table 5. 負担度スコアが100の 7 人の高齿者に対する介護の内容

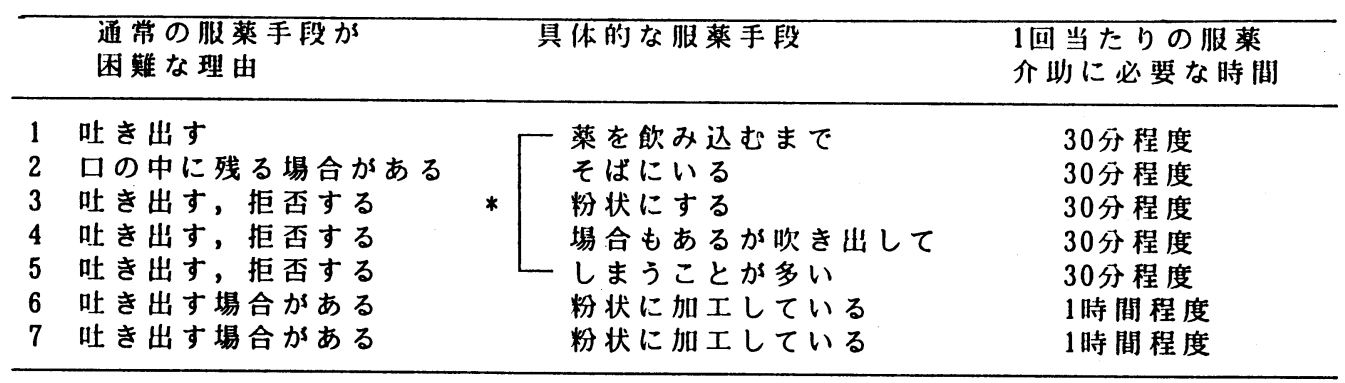

*1〜5については具体的な服薬手段は同しであった。 
る項目の水準の先頭に示されている数值は, Spearman の相関係数や重回㷌分析を行うにあ たって各水準に与えた係数で，例えば，Table 6 に拈いては，痴呆症なしの場合は 1 ，あれば 2 と いう係数を与えて解析を行った。

負担度スコアと有意な関連を示した疾患を
Table 6 にまとめた．相関係数/p 值のカラムに は上段に Spearman の相関係数，下段には関連 の有意性を調べる検定（Table 6〜9 そおいて 2 水準の場合はウイルコクソン検定， 3 水準以上の 場合は Spearman の相関係数に基ついた検定の $\mathrm{p}$ 值が示してある). 介助負担度スコアの平均值

Table 6. 疾患と負担度スコアの関連

\begin{tabular}{|c|c|c|c|c|c|c|c|}
\hline 項目 & 水渄 & 平均值 & $\mathrm{N}$ & 橙淮伲差 & 最小 & 最大 & 相関係数 /p 值 \\
\hline \multirow[t]{2}{*}{ 㾰呆症 } & 1なし & 18.5 & 215 & 22.8 & 0 & 100 & 0.287 \\
\hline & 2有り & 30.8 & 194 & 24.8 & 0 & 100 & $0.000 * *$ \\
\hline \multirow[t]{2}{*}{ 敛卒中 } & 1なし & 22.2 & 324 & 22.9 & 0 & 100 & 0.148 \\
\hline & 2有り & 32.7 & 85 & 28.8 & 0 & 100 & $0.003 * *$ \\
\hline
\end{tabular}

Table 7. 高齢者の基本運動機能の関連

\begin{tabular}{|c|c|c|c|c|c|c|c|}
\hline 項目 & 水淮 & 平均值 & $\mathrm{N}$ & 標淮偏差 & 最小 & 最大 & 相関係数 /p 值 \\
\hline 日常精神状態 & $\begin{array}{l}1 \text { 問題無 } \\
2 \text { 意識下 } \\
3 \text { 拒否的 } \\
4 \text { 自閉的 }\end{array}$ & $\begin{array}{l}19.4 \\
39.9 \\
40.0 \\
25.8\end{array}$ & $\begin{array}{r}294 \\
62 \\
29 \\
24\end{array}$ & $\begin{array}{l}21.9 \\
24.4 \\
30.1 \\
24.9\end{array}$ & $\begin{array}{l}0 \\
0 \\
0 \\
0\end{array}$ & $\begin{array}{l}100 \\
100 \\
100 \\
100\end{array}$ & $\begin{array}{l}0.323 \\
0.000 * *\end{array}$ \\
\hline 視力 & $\begin{array}{l}\text { 1問題無 } \\
\text { 2障害有 } \\
\text { 3全盲 }\end{array}$ & $\begin{array}{l}24.1 \\
25.7 \\
33.1\end{array}$ & $\begin{array}{r}379 \\
22 \\
8\end{array}$ & $\begin{array}{l}24.2 \\
26.4 \\
34.1\end{array}$ & $\begin{array}{l}0 \\
0 \\
0\end{array}$ & $\begin{array}{l}100 \\
100 \\
100\end{array}$ & $\begin{array}{l}0.036 \\
0.471\end{array}$ \\
\hline 聴力 & $\begin{array}{l}1 \text { 問題無 } \\
2 \text { 障害有 } \\
3 \text { 聴不能 }\end{array}$ & $\begin{array}{l}23.4 \\
24.7 \\
39.7\end{array}$ & $\begin{array}{r}298 \\
96 \\
15\end{array}$ & $\begin{array}{l}23.4 \\
25.7 \\
34.2\end{array}$ & $\begin{array}{l}0 \\
0 \\
0\end{array}$ & $\begin{array}{l}100 \\
100 \\
100\end{array}$ & $\begin{array}{l}0.057 \\
0.250\end{array}$ \\
\hline 閒口制限 & $\begin{array}{l}1 \text { 問題無 } \\
2 \text { 精神的に問題有 } \\
3 \text { 器質的に問題有 }\end{array}$ & $\begin{array}{l}22.0 \\
56.3 \\
50.6\end{array}$ & $\begin{array}{r}378 \\
15 \\
16\end{array}$ & $\begin{array}{l}22.6 \\
26.4 \\
31.9\end{array}$ & $\begin{array}{l}0 \\
0 \\
0\end{array}$ & $\begin{array}{l}100 \\
100 \\
100\end{array}$ & $\begin{array}{l}0.285 \\
0.000 * *\end{array}$ \\
\hline $\begin{array}{l}\text { 食物などの吐き出し } \\
\text { (精神的) }\end{array}$ & $\begin{array}{l}1 \text { 問題無 } \\
\text { 2吐出し有 }\end{array}$ & $\begin{array}{l}22.9 \\
55.8\end{array}$ & $\begin{array}{r}391 \\
18\end{array}$ & $\begin{array}{l}23.4 \\
29.0\end{array}$ & $\begin{array}{l}0 \\
0\end{array}$ & $\begin{array}{l}100 \\
100\end{array}$ & $\begin{array}{l}0.224 \\
0.000 * *\end{array}$ \\
\hline $\begin{array}{l}\text { 食物などをこぼす } \\
\text { (器質的) }\end{array}$ & $\begin{array}{l}\text { 1問題無 } \\
2 こ ほ ~\end{array}$ & $\begin{array}{l}20.8 \\
39.4\end{array}$ & $\begin{array}{r}331 \\
78\end{array}$ & $\begin{array}{l}23.4 \\
23.6\end{array}$ & $\begin{array}{l}0 \\
0\end{array}$ & $\begin{array}{l}100 \\
100\end{array}$ & $\begin{array}{l}0.341 \\
0.000 * *\end{array}$ \\
\hline $\begin{array}{l}\text { 悠下障害 } \\
\text { (固形物 ) }\end{array}$ & $\begin{array}{l}1 \text { 問題無 } \\
2 \text { むる } \\
3 \text { 呰下不能 }\end{array}$ & $\begin{array}{l}19.8 \\
43.8 \\
75.0\end{array}$ & $\begin{array}{r}345 \\
54 \\
10\end{array}$ & $\begin{array}{l}21.5 \\
24.1 \\
17.6\end{array}$ & $\begin{array}{r}0 \\
0 \\
60\end{array}$ & $\begin{array}{l}100 \\
100 \\
100\end{array}$ & $\begin{array}{l}0.423 \\
0.000 * *\end{array}$ \\
\hline $\begin{array}{c}\text { 㖓下障害 } \\
\text { (液体) }\end{array}$ & $\begin{array}{l}1 \text { 問題無 } \\
2 \text { む蕉下不能 }\end{array}$ & $\begin{array}{l}19.3 \\
40.9 \\
75.5\end{array}$ & $\begin{array}{r}330 \\
69 \\
10\end{array}$ & $\begin{array}{l}21.2 \\
24.8 \\
17.2\end{array}$ & $\begin{array}{r}0 \\
0 \\
60\end{array}$ & $\begin{array}{r}95 \\
100 \\
100\end{array}$ & $\begin{array}{l}0.422 \\
0.000 * *\end{array}$ \\
\hline 手の状態 & $\begin{array}{l}1 \text { 問題 無 } \\
2 \text { 部分介助 } \\
3 \text { 全介助 }\end{array}$ & $\begin{array}{r}9.6 \\
27.0 \\
45.2\end{array}$ & $\begin{array}{l}170 \\
136 \\
103\end{array}$ & $\begin{array}{l}13.6 \\
22.4 \\
25.1\end{array}$ & $\begin{array}{l}0 \\
0 \\
0\end{array}$ & $\begin{array}{r}70 \\
100 \\
100\end{array}$ & $\begin{array}{l}0.630 \\
0.000 * *\end{array}$ \\
\hline
\end{tabular}


は，痴呆症がない場合19に対して，痴呆症の場合 は31であり，痴呆症の高秢者については負担度ス コアは増加していた，脳卒中を有する高齢者につ いても同様に負担度スコアが増加していたが，他 の疾患を併発しても負担度スコアの増加傾向は認 められなかった，すなわち，ある高跘者が痴呆や 脳卒中に罹患していれば服薬介助の負担が増加す るが，慢性関節りューマチや前立腺肥大症等他の 疾患に罹患しているヶースの服薬介助の負担は, これらの疾患に罹患していないケースの服薬介助 の負担と比較して差がなかった.

負担度スコアとの関連が認められたのは日常精 神状態, 開口制限, 食物などの吐き出し（精神的 と器質的), 與下障害 (固形物之液体), 手の状態 であった (Table 7). 視力, 聴力の低下と負担度 スコアには関連はみられなかった。相関が最も高 かったのは手の状態で, 問題がない場合の平均值 が10点であるのに比し，部分介助が必要な高齢者 では27点, 全介助が必要な場合は45点となった.
日常精神状態については, 問題がない人19点に比 べて意識低下あるいは拒否的な場合は40点に増加 した．開口制限がある場合は精神的と器質的な問 題でそれぞれ負担度スコアが，56，51点に増加し た. 與下障害についても負担度と関連がみられ, 特に與下不能であった 10 人については負担度の平 均は75点で，最低でも60点であった．亜下不能の 高秢者に対してはチューブを用いて薬を与兄てい る場合が多かったが，チューブの使用については 高齢者が嫌がる場合が多いとのことであった。

活動機能レベルと負担度スコアとの関連では (Table 8)，いずれの指標も5のケースの機能レ ベルが最も高く，数字が小さくなるにつれて機能 レベルが低下し，0は機能がほとんど廃絶してい ることを意味している．4 種類の活動機能レベル ですべて 0.5 以上の強い関連がある．相関係数の 符号がマイナスになっているのは活動機能レベル の悪化とともに係数が小さくなるようにスコア化 したためである. 各水準の負担度スコアの平均值

Table 8. 活動機能レベルと負担度スコアの関連

\begin{tabular}{|c|c|c|c|c|c|c|c|}
\hline 项目 & 水準 & 平均 值 & $\mathrm{N}$ & 榡準傭差 & 收小 & 破大 & 机荓係数 /p值 \\
\hline 食事 & $\begin{array}{l}5 \text { 自立 } \\
4 \text { 境界 } \\
3 \text { 食事介助容易 } \\
2 \text { 食事介助難 } \\
1 \text { 鼻坥栄善 }\end{array}$ & $\begin{array}{l}13.1 \\
24.0 \\
40.0 \\
46.1 \\
76.4\end{array}$ & $\begin{array}{r}198 \\
107 \\
55 \\
38 \\
11\end{array}$ & $\begin{array}{l}17.3 \\
17.8 \\
25.9 \\
27.3 \\
16.6\end{array}$ & $\begin{array}{r}0 \\
0 \\
0 \\
0 \\
60\end{array}$ & $\begin{array}{r}90 \\
80 \\
100 \\
100 \\
100\end{array}$ & $\begin{array}{l}-0.559 \\
0.000 * *\end{array}$ \\
\hline 排泄 & 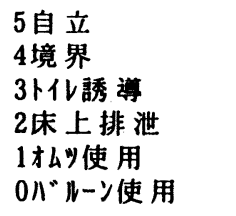 & $\begin{array}{r}8.0 \\
13.3 \\
29.9 \\
28.4 \\
35.0 \\
43.0\end{array}$ & $\begin{array}{r}98 \\
79 \\
38 \\
22 \\
161 \\
17\end{array}$ & $\begin{array}{l}13.3 \\
16.9 \\
20.4 \\
17.3 \\
26.1 \\
30.6\end{array}$ & $\begin{array}{r}0 \\
0 \\
0 \\
10 \\
0 \\
0\end{array}$ & $\begin{array}{r}70 \\
90 \\
100 \\
60 \\
100 \\
100\end{array}$ & $\begin{array}{l}-0.557 \\
0.000 * *\end{array}$ \\
\hline 精神 & $\begin{array}{l}5 \text { 自立 } \\
4 \text { 境界 } \\
3 \text { 軽度低下 } \\
2 \text { 中度低下 } \\
1 \text { 重度低下 } \\
0 \text { 傾眠 }\end{array}$ & $\begin{array}{r}7.5 \\
20.5 \\
29.2 \\
30.0 \\
47.4 \\
66.7\end{array}$ & $\begin{array}{r}94 \\
102 \\
88 \\
80 \\
42 \\
3\end{array}$ & $\begin{array}{l}12.5 \\
21.3 \\
23.3 \\
23.0 \\
26.6 \\
57.7\end{array}$ & $\begin{array}{r}0 \\
0 \\
0 \\
0 \\
10 \\
0\end{array}$ & $\begin{array}{r}70 \\
90 \\
100 \\
100 \\
100 \\
100\end{array}$ & $\begin{array}{l}-0.520 \\
0.000 * *\end{array}$ \\
\hline 活 動 & $\begin{array}{l}5 \text { 自立 } \\
4 \text { 境界 } \\
3 \text { 步行時観察要 } \\
2 \text { 自力座位可能 } \\
1 \text { 体位変換可能 } \\
0 \text { 体位変換不能 }\end{array}$ & $\begin{array}{r}6.6 \\
12.0 \\
21.6 \\
30.0 \\
32.0 \\
48.8\end{array}$ & $\begin{array}{l}70 \\
84 \\
81 \\
44 \\
55 \\
75\end{array}$ & $\begin{array}{l}12.2 \\
12.1 \\
19.2 \\
22.1 \\
25.0 \\
27.1\end{array}$ & $\begin{array}{l}0 \\
0 \\
0 \\
0 \\
0 \\
0\end{array}$ & $\begin{array}{r}70 \\
50 \\
90 \\
90 \\
100 \\
100\end{array}$ & $\begin{array}{l}-0.601 \\
0.000 * *\end{array}$ \\
\hline
\end{tabular}


Table 9. 服薬介助の工夫と負担度スコアの工夫の関連

\begin{tabular}{|c|c|c|c|c|c|c|c|}
\hline 項目 & 水潐 & 平均值 & $\mathrm{N}$ & 䤂淮偏差 & 最小 & 最大 & 相関係数 / $\mathrm{p}$ 值 \\
\hline $\begin{array}{l}\text { 何らかの特別な工夫 } \\
\text { を行う }\end{array}$ & $\begin{array}{l}\text { 1しない } \\
2 す る\end{array}$ & $\begin{array}{l}20.9 \\
50.6\end{array}$ & $\begin{array}{r}362 \\
47\end{array}$ & $\begin{array}{l}21.6 \\
29.9\end{array}$ & $\begin{array}{l}0 \\
0\end{array}$ & $\begin{array}{l}100 \\
100\end{array}$ & $\begin{array}{l}0.307 \\
0.000 * *\end{array}$ \\
\hline ペースト状にする & $\begin{array}{l}1 し な い \\
2 す る\end{array}$ & $\begin{array}{l}23.9 \\
56.0\end{array}$ & $\begin{array}{r}404 \\
5\end{array}$ & $\begin{array}{l}24.4 \\
18.2\end{array}$ & $\begin{array}{r}0 \\
30\end{array}$ & $\begin{array}{r}100 \\
80\end{array}$ & $\begin{array}{l}0.138 \\
0.005 * *\end{array}$ \\
\hline 食事に混せる & $\begin{array}{l}\text { 1しない } \\
2 す る\end{array}$ & $\begin{array}{l}22.7 \\
53.8\end{array}$ & $\begin{array}{r}388 \\
21\end{array}$ & $\begin{array}{l}23.5 \\
26.1\end{array}$ & $\begin{array}{l}0 \\
0\end{array}$ & $\begin{array}{l}100 \\
100\end{array}$ & $\begin{array}{l}0.237 \\
0.000 * *\end{array}$ \\
\hline 食事以外の食物に混ぜる & $\begin{array}{l}\text { 1しない } \\
2 す る\end{array}$ & $\begin{array}{l}23.5 \\
58.0\end{array}$ & $\begin{array}{r}399 \\
10\end{array}$ & $\begin{array}{l}24.1 \\
18.1\end{array}$ & $\begin{array}{r}0 \\
30\end{array}$ & $\begin{array}{r}100 \\
80\end{array}$ & $\begin{array}{l}0.202 \\
0.000 * *\end{array}$ \\
\hline オブラートで包む & $\begin{array}{l}1 し な い \\
2 す る\end{array}$ & $\begin{array}{l}24.4 \\
21.3\end{array}$ & $\begin{array}{r}401 \\
8\end{array}$ & $\begin{array}{l}24.5 \\
25.9\end{array}$ & $\begin{array}{l}0 \\
0\end{array}$ & $\begin{array}{r}100 \\
70\end{array}$ & $\begin{array}{r}-0.026 \\
0.601\end{array}$ \\
\hline $\begin{array}{l}\text { 和工 } \\
\text { (粉砕・脱カブセル) }\end{array}$ & $\begin{array}{l}\text { 1しない } \\
2 す る\end{array}$ & $\begin{array}{l}21.9 \\
57.7\end{array}$ & $\begin{array}{r}381 \\
28\end{array}$ & $\begin{array}{l}22.4 \\
28.7\end{array}$ & $\begin{array}{l}0 \\
0\end{array}$ & $\begin{array}{l}100 \\
100\end{array}$ & $\begin{array}{l}0.303 \\
0.000 * *\end{array}$ \\
\hline その他 & $\begin{array}{l}\text { 1しない } \\
\text { 2する }\end{array}$ & $\begin{array}{l}22.6 \\
58.0\end{array}$ & $\begin{array}{r}389 \\
20\end{array}$ & $\begin{array}{l}22.9 \\
30.5\end{array}$ & $\begin{array}{l}0 \\
0\end{array}$ & $\begin{array}{l}100 \\
100\end{array}$ & $\begin{array}{l}0.242 \\
0.000 * *\end{array}$ \\
\hline
\end{tabular}

をみると活動機能レベルの悪化とともに用量相関 的にスコアが上昇することがわかる.

服薬介助の工夫と負担度スコアの関連では (Table 9), 服薬させるための特別な工夫を行っ ている人は 1 割強であり，オブラートで包むを除 いて，工夫を行うことによって負担度スコアの平 均值はいずれも50点を越える. 高龄者が服薬しや すいよら介護者がやむをえず工夫することが，介 護者の負担を大きく増加させることが示唆され る.

\section{3. 重回㷌分析}

前節の解析結果より様々な要因が負担度スコア に影響を与えることがわかった。しかしながら要 因間には高い関連が存在する. 例えば活動機能レ ベルの精神と活動には0.50の相関があり, 精神レ ベルの低下とともに活動機能レベルも低下寸るの で, 精神レベルの負担度との関連が本質的なもの なのか，活動レベルの低下を通じた間接的なもの であるかは不明確である. そこで負担度スコアに 影響を与える要因の構造を重回㷌分析によって探 索した。

高齢者側の因子である年路, 性別, 疾患の有無 (14変数), 問題行動の有無 (8 変数), 基本運動
機能 (9 変数), 活動機能レベル ( 4 変数), 施設 (5つのダミ一変数によって表した), 服薬剤数な どの計 43 説明変数を候補として総当たり法によっ て変数選択を行った. Table 10 では最初に 1 変 数を含むモデルの中で説明力が高い順に10種類示 し，その後でモデルの変数が $2 \sim 10$ までのそれぞ れの場合について，説明力の高いモデルを高い方 から 2 種類示した．施設については施設番号 6 の

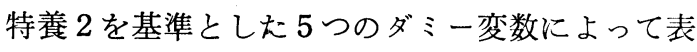
した．例えば，施設間差 (1-6) は施設番号 1 の老 病 1 と特養 2 の違いを表すダミ一变数である.

モデルに含まれる変数の数ごとに，最も説明 力が高いモデルの寄与率を比較すると，1变数 (0.339), 2 変数 $(0.465), 3$ 変数 $(0.512), 4$ 变数 $(0.536), 5$ 変数 $(0.552), 6$ 変数 $(0.573), 7$ 变数 $(0.586), 8$ 变数 $(0.595), 9$ 変数 $(0.603), 10$ 变数 (0.608) となり，8変数以上追加しても，モデル の寄与率の改善は $1 \%$ よ小さいので, 変数の数 は 8 程度が適当であると考觉られた。

モデルに含まれる変数が 8 個のモデルの中で, 最も寄与率が高いモデルは, 服薬剂数, 精神, 活 動, 臙下障害 (固形物), 手の状態, 施設間差のダ ミ一変数 $3 つ((1-6),(2-6),(4-6))$ であった. 
Table 10. 総当たり法による変数選択の結果

\begin{tabular}{|c|c|c|}
\hline 変数の数 & 寄与率 & モデルに含まれる変数 \\
\hline 1 & 0.339 & 食事 \\
\hline 1 & 0.337 & 手の状態 \\
\hline 1 & 0.335 & 活 動 \\
\hline 1 & 0.257 & 排泄 \\
\hline 1 & 0.227 & 精 神 \\
\hline 1 & 0.221 & 施設間差 $(1-6)$ \\
\hline 1 & 0.215 & 橏下障害（固形物） \\
\hline 1 & 0.213 & 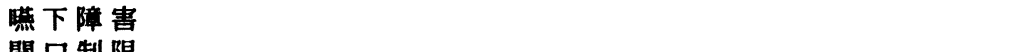 \\
\hline 1 & 0.097 & $\begin{array}{l}\text { 開口制限 } \\
\text { 食物なとをこほ（器質的） }\end{array}$ \\
\hline 1 & 0.089 & 食物なとをこほす（器質的） \\
\hline 2 & 0.465 & 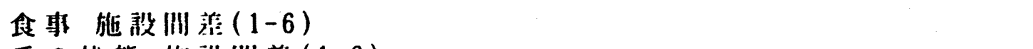 \\
\hline 2 & 0.465 & 手の状热 施没洲差 $(1-6)$ \\
\hline 3 & 0.512 & 手の状態 食事 施設間差 $(1-6)$ \\
\hline 3 & 0.509 & 食事 活動 施設間差 (1-6) \\
\hline 4 & 0.536 & 手の状態 食事 施設間差 $(1-6)$ 施設間差 $(2-6)$ \\
\hline 4 & 0.529 & 嘻下噇害（固形物）手の状態 活動 施設間差（1-6） \\
\hline 5 & 0.552 & 手の状態 食事 施設間差 $(1-6)$ 施設間差 (2-6) 施設間差 $(3-6)$ \\
\hline 5 & 0.552 & 呰下障害（固非物）精神＼cjkstart活動＼cjkstart施設间差（1-6）施設間差（2-6） \\
\hline 6 & 0.573 & 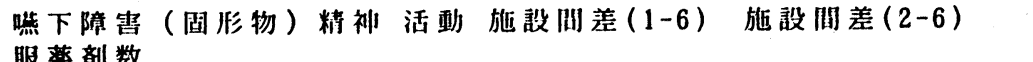 \\
\hline 6 & 0.572 & 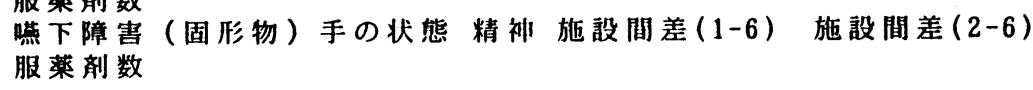 \\
\hline 7 & 0.586 & $\begin{array}{l}\text { 㖓下障害（固形物）手の状態 精神 活動 施設間差 }(1-6) \\
\text { 施設間差 }(2-6) \text { 服薬剂数 }\end{array}$ \\
\hline 7 & 0.584 & 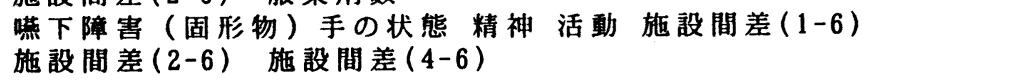 \\
\hline
\end{tabular}

\begin{tabular}{|c|c|c|}
\hline 8 & 0.595 & 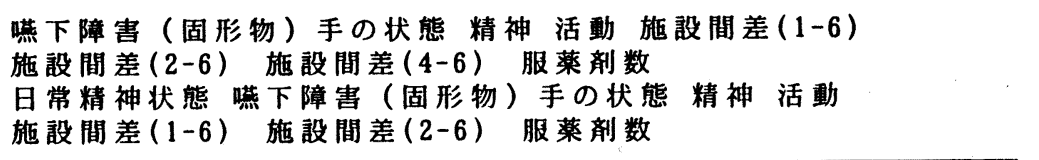 \\
\hline 9 & 0.603 & 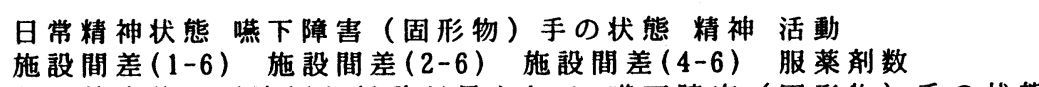 \\
\hline 9 & 0.602 & 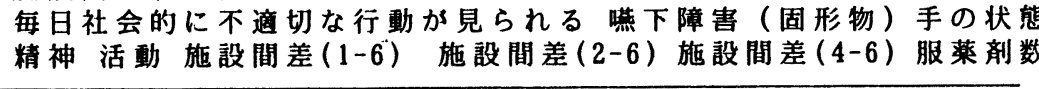 \\
\hline 10 & 0.608 & $\begin{array}{l}\text { 便秘症 日常精神状態 㗪下障害 (固形物) 手の状態 精神 活動 } \\
\text { 施設間差 }(1-6) \text { 施設間差 }(2-6) \text { 施設間差 }(4-6) \text { 服薬剂数 }\end{array}$ \\
\hline 10 & 0.608 & 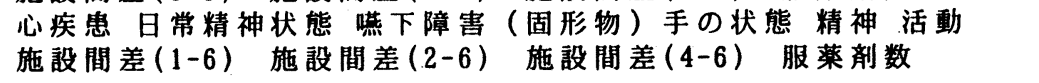 \\
\hline
\end{tabular}

施設間差のダミー変数を $2 つ((3-6),(5-6))$ 加 えた10変数のモデルについての解析結果から燕 下障害が，“問題なし”から“むせる”になると 9.55点, “問題なし”から“與下障害”になると $9.55 \times 2$ 点, 平均点に負担度が増加することがわ
かる (Table 11). 例えば, 薬を 3 剂服用し, 精 神機能レベル 5 (自立), 活動機能レベル 2 (自立 座位可能), 與下障害がなく, 手に障害のある脳卒 中の後遺症のある高㱓者が老病 2 に入居した場 合 ; 
病院薬学 Vol.21, No.4 (1995)

Table 11. 固定モデルによる重回帰分析の結果

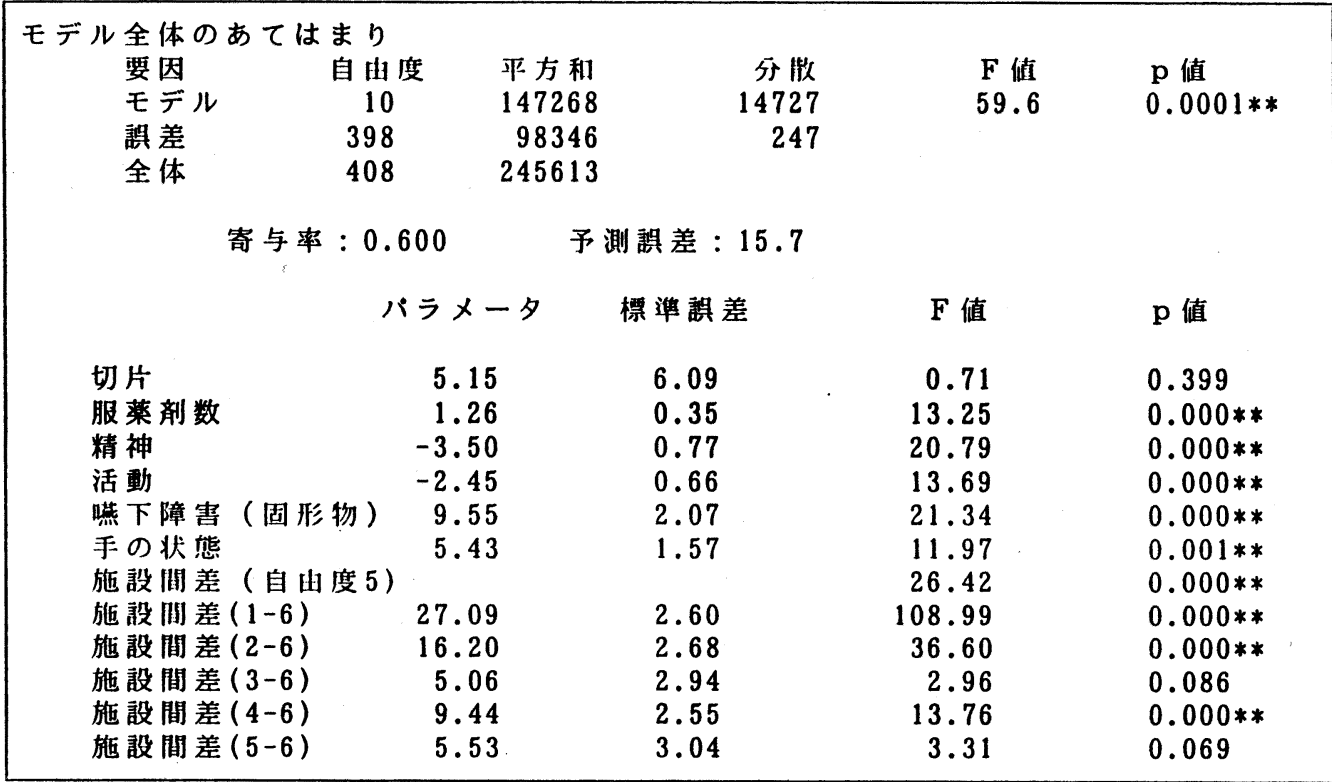

$\underline{23.14}=\underline{5.15}+\underline{1.26} \times 3-\underline{3.50} \times 5-\underline{2.45} \times 2+$ 予測点数 切片 剂数 精神 活動 $9.55 \times 1+5.43 \times 2+16.20 \times 1$

曣下障害 手の状態 施設間差 (2-6)

となりこの高龄者の服薬介助負担度は約 23 点であ ることが予測される.

本モデルの寄与率は0.60であり, 負担度スコア 全体の変動の $60 \%$ ぞモデルによって説明できる.

これを重相関係数に直すと 0.77 になる. F 值 (Table 11) は嚥下障害 (固形物), 精神, 活動, 薬の剂数, 手の状態の順であり，いずれの要因も $5 \%$ 水準で有意であった。これらの因子が重な りあって介護の負担度を増大させている。また， 負担度スコアに大きな施設間差が存在した。施設 間差（1-6）と（2-6）のF值が大きく, 重回帰モ デルによって, 高齢者の機能レベルの違いをモデ ルに取り込んだ後でも，老病 1 は，基準とした特 養 2 より平均で 27 点, 老病 2 は 16 点亡, 高くなっ ていた。

\section{考察}

調査の問題点について述べる. 調査票について あらかじめ小規模のパイロット研究等により, 内
容, 実行可能性等を検討したが，各施設ではこの ような調査を行ったのが初めてであったため，調 查票を記入したスタッフの中には戸惑いがあっ た. 老健 2 では, 服薬介助負担度スコアを高齢者 の介助全般の負担度と誤解して, 平均で50点を越 すよらな高めのスコアが当初つけられた，そのよ らな言葉の誤解によって，実態に合わない回答が 調查票に記載されている場合も存在すると考えら れる.

調査を行った対象は，高踹者の主な療養施設で ある老人病院, 老人保健施設, 特別養護老人ホー ムについて各 2 施設ずつであるが，これらの施設 の入居者の機能レベル，医療レベル等のわが国の 全体の中での位置付けが明らかでないため, 日本 の高齢者施設全体について結果を一般化すること は困難である、しかしながら，対象とした集団の 年齢構成, 性比は寺崎ら ${ }^{8)}$ が老人病院 3 施設, 老 人保健施設 4 施設, 特別養護老人ホーム 2 施設で 行った研究と同様であった。

このように本研究では噯昧さを含んだスコアを 用い，かつ一般化するのにやや問題のある集団を 対象したものではあるが，QOL についての重要 性の認識の高まり，高秢化社会を迎えて在宅を含 
めた介護施設が増加していくのに対応し，人的資 源をこれらに投入しなければならないことを考兄 合わせると, 高龄者が服薬するときの負荷, 介助 する側の負担度を定量的に評価することは増々重 要になってくると考えられる. 調查に拉ける今後 の課題としては, 同じ高㱓者に対して服薬介助ス コアを複数回評価したときの再現性, 評価者が変 わったときの変動等のスコアの信頼性についての 評価が上げられる. 更に在宅介護を含めて研究対 象を広げ，一般化可能性についての検討, 同一施 設での経時変化を追うことも大切であろう.

次に解析の問題点について述べる.

服薬介助負担度スコアの分布は右に裾を引いた ひずんだ分布であった（Fig．1）。このような分 布に対して正規分布を仮定した重回帰分析などの 統計手法を適用するのは適切ではない，本研究で は，分布を平方根変換して正規分布に近づけた場 合についても解析を試み, 同様の結果が得られる ことを確認している. 変数変換した方がモデルの 適合度が若干改善するが，本質的な点が变わらな かったため，解釈しやすさを優先して生データの 解析結果について示した。

重回帰分析では, 説明変数と服薬介護負担度ス コアの間に線形性を仮定した，本来カテゴリー変 数については，施設差をモデル化するのに用いた ように水準数-1のダミ一変数を用いるのが望まし いが，サンプルサイズとの関係であまり複雑なモ デルをあてはめることが困難であり，まだほぼ線 形的に変化していることが確認できたため線形性 を仮定した (Table 7,8). モデルのあてはまりに ついては，標準的な回帰診断の方法9)を用いて異 常值などの存在がないことを事後的に確認してい る.
施設間差については老人病院で平均スコアが高 くなる傾向があった．2つの老人病院（特に老病 1）では，剂型の加工あるいは特別な工夫を行っ ている割合が高く，これに伴い負担度が増してい ると考光られる。

負担度スコアについては“食事準備”に相当す る20点前後と答えた人が多かったが，老人病院で はかなり負担のかかる50点以上の高齢者が $45 \%$ 存 在した．負担度を増加させる高龄者側の要因とし ては與下障害, 精神レベルの低下, 活動レベルの 低下，薬の剂数の増加，手の状態の悪化等があっ た。 また負担度の施設間差が大きく，老人病院で は特に負担度スコアが高かった。

正常人にとっては何でもない服薬行動が，機能 が低下した高齢者ではかなりの負荷となり，それ にともない剂型の加工，ご飯にまぜるなどの工夫 が行われ，介護者の負担が増大しているケースが 老人病院等では少なからず存在する事実が判明し た。これに対し老人保健施設，特別養護老人ホー 厶の計 4 施設ではあまり服薬介助の負担度は高く なかったが，これらの施設では，剂型の加工など の服薬介助が行われないことによって，高秢者の 負担の増加，あるいはコンプライアンスが低下し ている可能性がある.

薬剤の持つ薬理作用は, 正しい方法で投与され て初めて適正な効果が期待できる，錠剂を粉砕し て投与した場合には，薬効が消失したり，副作用 が発現したりする危険性が大きい，特に徐放剤や 腸溶錠を加工した場合はこのような可能性が高 い.今回調查した中で散剂が存在するのに錠剂を 粉砕していた薬剤が，25種類あった ${ }^{10)}$. 今後, 在 宅介護が一般化していった場合には，高㱓者の家 族が服薬の介助を行う場合が増えてくると考えら

Table 12. 剂型の加工，特別な工夫をしている割合

\begin{tabular}{|c|c|c|c|c|c|c|c|c|}
\hline & & 老病 1 & 老㾈 2 & 老健 1 & 老健 2 & 特養 1 & 特養 2 & 計 \\
\hline $\begin{array}{l}\text { 剂型の } \\
\text { 加工 }\end{array}$ & $\begin{array}{l}\text { 度数 } \\
(\%)\end{array}$ & $\begin{array}{l}21 \\
26.6\end{array}$ & $\begin{array}{l}2 \\
3.0\end{array}$ & $\begin{array}{l}1 \\
1.6\end{array}$ & $\begin{array}{l}2 \\
2.6\end{array}$ & $\begin{array}{l}0 \\
2.0\end{array}$ & $\begin{array}{l}1 \\
1.3\end{array}$ & $\begin{array}{l}27 \\
6.6\end{array}$ \\
\hline $\begin{array}{l}\text { 特別な } \\
\text { 工夫 }\end{array}$ & $\begin{array}{l}\text { 度数 } \\
(\%)\end{array}$ & $\begin{array}{l}21 \\
26.6\end{array}$ & $\begin{array}{c}8 \\
12.1\end{array}$ & $\begin{array}{l}2 \\
3.3\end{array}$ & $\begin{array}{l}6 \\
7.7\end{array}$ & $\begin{array}{l}1 \\
2.0\end{array}$ & $\begin{array}{c}9 \\
11.8\end{array}$ & $\begin{array}{l}47 \\
11.5\end{array}$ \\
\hline
\end{tabular}


れる、家族は通常医療従事者ではなく, 剂型加工 が勝手に行われば予期せぬ作用が発現する可能性 がある.このような事故を未然に防ぐためには， 剂型の加工の可否 ${ }^{11}$ についての情報が一般の人に も公開される必要があると考兄られる．情報公開 のためには薬の相談室等の活動が大変注目され る ${ }^{12)}$. あわせて服薬者の負荷と介護者の負担を減 らすため, 製薬メーカーは高㱓者に向いた, 服薬 しやすい剤型を開発する必要があると考兄られ $る^{13,14)}$. また今回の調査の結果, 高齢者の手の状 態が服薬介助の負担と密接に関連しており, 包装 にも工夫する必要があるだろら ${ }^{15,16)}$.

謝辞 本調査に扣いて, 調查協力施設のスタッフの 皆さんに大変お世話になりました。またエーザイ株式 会社から調查の援助などを受けました。

\section{引用文 献}

1）石橋丸應, 本屋敏郎, 宔田優子, 九州薬学会会 報, 45, 121-128 (1991).

2) 山口辰哉, 本屋敏郎, 石橋丸應, 有馬新一, 田中 弘, 熊副マサ子, 薬局, 41，37-44 (1990).

3) 照井聖比古, 長内尚子, 尾崎祥子, 藤田裕栄, 古 郡昭彦, 菅原和信, 医薬品相互作用研究, 13,11-
24 (1989).

4）高橋 泰, 浜田知久馬, 中島 研, 清水聖子, 病 院薬学, 投稿中 (1995).

5) 筒井孝子, 社会福祉学, 34, 43-82 (1994).

6) 市川伸一, 大橋靖雄, 岸本淳司, 浜田知久馬他, “SAS によるデータ解析入門”, 第 2 版, 東京大 学出版会, 東京, 1993, pp.157-190,

7）奥野忠一，芳賀敏郎，久米 均, 吉沢 正, “多 变量解析”, 日科技連出版社, 東京, 1971, pp. 25-108.

8）寺崎 亿, 梅里良正, 久保喜子, 大道 久, 日本 公衛誌, 41, 671-681 (1994).

9) A.C.Atkinson, "Plots, Transformations, and Regression", Clarendon Press, Oxford, 1985, pp. 1-38.

10）浜田知久馬, 中島 研, 高橋 泰, 福室憲治, 未 発表.

11）川本由加里, 結城祥充, 岩井新治, 芦崎達三, 大 谷隆之, 高橋保志, 富所謙吉, 日本病院薬剤師会 誌, 28, 43-47 (1992).

12）小俣祥忠, 石川靖二, 第59会九州山口薬学大会予 稿集, 沖縄, 1994, p. 125.

13）吉野清高, 順天堂医学, 37, 26-31 (1991).

14) 杉原正泰, ファルマシァ, 25, 895-900 (1989).

15) 近藤光子, Med.Pharm., 22, 44-47 (1988).

16）木村徳三, 月刊薬事, 31, 29-33 (1989). 